ELKOM, Vol.12, No.2, Desember 2019, pp. 63 - 71

p-ISSN : 1907-0012 (print)

e-ISSN : 2714-5417 (online)

http://journa.stekom.ac.id/index.php/elkom

- page 63

\title{
Pemrograman Berorientasi Obyek Untuk Meningkatkan Kinerja Laporan Keuangan Pada Toko YK
}

\author{
Indra Ava Dianta ${ }^{1}$, Desy Setyowati ${ }^{2}$ \\ ${ }^{1}$ Progdi Teknik Komputer STEKOM Semarang \\ indra@stekom.ac.id \\ ${ }^{2}$ Progdi Komputerisasi Akuntansi STEKOM Semarang \\ desysetyowati25@gmail.com \\ Jl. Majapahit 605, Semarang, telp/fax : 024-6717201-02
}

\section{ARTICLE INFO \\ Article history: \\ Received 30 November 2019 \\ Received in revised form 2 Desember 2019 \\ Accepted 10 Desember 2019 \\ Available online 12 Desember 2019}

\begin{abstract}
YK store is a UKM (small and medium enterprises) whose activities are buying and selling wholesale goods such as oil, spices, noodles, flour, coconut milk, pepper, and others in moderation (wholesale). YK store manager does not have a bookkeeping application system for the process of making financial reports in accordance with financial accounting standards, and there is no support system for merchandise inventory which supports buying and selling transactions. Information systems for managing merchandise needed by companies to determine value according to transactions, for financial statements will use a journal of eternal methods to buy and sell transactions then post them to the ledger and make financial reports for all businesses. Bookkeeping information system design using microsoft visual basic 6.0 , xammp as a server and mysql as a database. The results obtained from this information system can contain reports obtained in accordance with the types and financial statements for business activities. Keywords: Computerized Accounting, Merchandise Inventory, Financial Statements, Perpetual Methods, Visual Basic.
\end{abstract}

\section{PENDAHULUAN}

Teknologi informasi yang semakin berkembang saat ini tentu sangat membantu dalam mendapatkan dan mengolah sebuah informasi, tujuan dikembangkannya teknologi informasi yaitu untuk memberikan kemudahan dalam melakukan tugas dan kepentingan manusia dalam segala bidang, salah satunya didunia pekerjaan. Dalam sebuah badan usaha atau perusahaan penggunaan sistem berbasis komputer dalam bidang keuangan mungkin sudah tidak asing lagi, karena keuangan merupakan faktor penting yang berpengaruh pada perkembangan sebuah perusahaan [1].

Akuntansi memegang peranan penting bagi suatu perusahaan karena akuntansi adalah bahasa bisnis, akuntansi tidak hanya untuk perusahaan bisnis tetapi semua perusahaan membutuhkan akuntansi, dikarena setiap perusahaan perlu melaporkan keadaan finansial dan kinerja dari aspek keuangan. Menurut Kieso mengatakan akuntansi sebagai suatu teknik prosedur dengan input data/informasi dan hasilnya berupa informasi dan laporan keuangan yang berguna bagi pihak dalam maupun pihak luar perusahaan. Unsur sumber daya manusia (SDM) juga memegang peran penting dalam laporan keuangan sebagai penyusunan dan pemeriksa laporan keuangan, sistem kompuer hanya membantu proses tetapi yang menentukan proses dan seperti apa laporanya adalah SDM [2]. 
Perusahaan Dagang merupakan perusahaan yang memulai proses bisnisnya dengan melakukan pembelian barang dagangan kemudian melakukan penjualan barang dagangan tersebut tanpa mengubah bentuk dasar dari barang dagangan yang dibeli tersebut. Pada umumnya suatu perusahaan didirikan tentunya mempunyai berbagai tujuan keinginan yang dicapai. Tujuan pokoknya adalah untuk mendapatkan keuntungan (laba). Transaksi-transaksi yang terjadi serta metode pengelolaan persediaan barang dari perusahaan dagang akan mempengaruhi perhitungan dalam penyususan laporan finansial perusahaan tersebut [3].

Toko YK adalah UKM (Usaha Kecil Menengah) yang kegiatanya membeli dan menjual barang dagangan kelontong seperti, minyak, penyedap rasa, mie, tepung, santan, lada bubuk, dan lain-lain dalam jumlah sedang (Grosir). Selama menjalankan kegiatan usaha, Toko YK menggunakan Microsoft Excel untuk mengelola persediaan barang dagangan dan untuk penyusunan dan perhitungan laporan keuangannya, untuk pencatatan transaksi pembelian, penjualan dan yang lainnya dibuatkan bukti nota dan diarsipkan ke dalam buku transaksi harian, penyusunan laporan transaksi setiap harinya membutuhkan rentang waktu yang sedikit lama, jika pemilik ingin melihat laporan persediaan barang dagangan untuk kepentingan pemesanan barang belum bisa secara cepat, harus menunggu dibuatkan laporannya terlebih dahulu, sedangkan untuk laporan keuangan setiap bulan disusun setelah akhir bulan dan membutuhkan waktu satu sampai dua minggu, dengan adanya masalah tersebut maka bisa mempengaruhi transaksi usaha pada periode selanjutnya dan secara langsung pasti berpengaruh pada pendapatan usaha. Selain itu berdasarkan informasi yang saya dapat Toko YK memang belum mempunyai sistem informasi akuntansi utama untuk menghasilkan laporan keuangan dan sistem pengelolaan persediaan barang dagangan

Penelitian ini memiliki tujuan untuk melakukan pengelolaan atas transaksi pembelian dan penjualan yang langsung terhubung dengan persediaan barang dagangan dan pengelolaan bukti-bukti transaksi pada Toko Yk agar menghasilkan informasi keuangan yang up-to-date sehingga kinerja perusahaan menjadi lebih optimal. Hasil penelitiaan ini diharapkan dapat membantu kesulitan dalam pembuatan dan penyususnan laporan keuangan atau pembukuan pada Toko YK.

\section{METODE PENGEMBANGAN}

Metode penelitian yang digunakan yaitu dengan pendekatan model research and development (Borg and Gall, 1983) [4]. Suatu produk tertentu yang diuji keefektifan produknya sehingga dapat menghasilkan suatu produk baru atau pengembagan dari sistem tersebut.

\section{A. Metode Penelitian}

Secara konseptual, siklus R\&D terdapat 10 langkah umum tetapi, penulis melakukan penelitian menggunakan langkah yang dapat diuraikan sebagai berikut:

1) Pengumpulan data awal (Research and information)

Dalam tahap ini yaitu mencari informasi atau data terkait dengan yang dibutuhkan, melakukan studi literatur yang berkaitan dengan permasalahan yang dikaji serta memberikan hasil dari pengindentifikasian yang dapat menyelesaikan masalah tersebut.

2) Perencanaan (Planning)

Tahap ini merumuskan perencanaan yang berkaitan dengan permasalasahan, menentukan tujuan yang akan dicapai pada setiap tahapan.

3) Pengembangan produk awal (Develop Preliminary form of product)

Menguraikan daftar produk yang ingin dibuat secarang lengkap. Termasuk menyiapkan komponen pendukung seperti menyajikan pedomandan buku petunjuk dan melakukan penilaian kelayakan terhadap alat pendukung.

4) Ujicoba awal (Preliminary field testing)

ELKOM Vol. 12, No. 2, Desember 2019: $63-71$ 
Pengecekan terhadap produk dalam ukuran terbatas, yang dilaksanakan beberapa kali sesuai dengan keperluan. Pada bagian ini pengumpulan dan kajian data dapat dilakukan melalui cara wawanara, observasi.

5) Revisi Produk (Main product revision)

Melakukan penilaian atau pemeriksaan dengan upaya analisis dan evaluasi logika. Perbaikan ini bisa lebih dari satu kali, sesuai hasil yang ditujukkan dalam ujicoba terbatas, sehingga diperoleh produk (model utama yang tersedia diuji lebih luas).

6) Uji Coba Produk (Main field testing) Ujicoba yang melibatkan pakar dari STEKOM dan perusahaan.

7) Penerapan Prototype pada tempat penelitian (Implementation Prototype) Langkah penerapan prototype dan menyebarluaskan produk atau model yang dikembangkan.

Dimulai dengan Pengumpulan Data, perencanaan untuk mengetahui desain awal pengembangan sistem, pengembangan produk awal, uji coba awal, revisi produk, uji coba produk, setelah itu implementasi.

\section{B. Validasi Desain}

Validasi produk merupakan salah satu proses pengembangan yang dilakukan guna mengetahui tingkat keefektifan produk tersebut. Uji validitas melibatkan para pakar internal serta lapangan (pengguna atau user) dengan penilaian menggunakan angket. Dalam Tabel 1 dan Tabel 2 dijelaskan bahwa penilaian menggunakan angket, terbagi atas 2 angket, yakni angket ditujukan bagi validator (pakar internal), bagian admin, pembukuan dan pimpinan (pengguna produk).

Tabel 1. Angket Validasi Pakar Internal

\begin{tabular}{|c|c|c|c|c|c|}
\hline No & Indikator & 1 & 2 & 3 & 4 \\
\hline 1 & $\begin{array}{l}\text { Apakah desain arsitektur sistem sudah mendefinisikan komponen } \\
\text { dengan strukstur dapat menjawab kebutuhan sistem? }\end{array}$ & & & & $\sqrt{ }$ \\
\hline 2 & $\begin{array}{l}\text { Apakah perancangan database yang dibangun melalui normalisasi } \\
\text { menghasilkan susunan tabel yang tidak redudant (double)? }\end{array}$ & & & $\sqrt{ }$ & \\
\hline 3 & $\begin{array}{l}\text { Apakah desain Entity Relations Diagram (ERD) sudah menentukan } \\
\text { hubungan relasi antara entitasnya dengan benar? }\end{array}$ & & & & $\sqrt{ }$ \\
\hline 4 & $\begin{array}{l}\text { Apakah desain Entity Relations Diagram (ERD) sudah } \\
\text { menggambarkan seluruh entitas beserta atributnya dengan benar } \\
\text { sesuai dengan sistem yang dibangun? }\end{array}$ & & & & $\sqrt{ }$ \\
\hline 5 & $\begin{array}{l}\text { Apakah desain Flow Of Document memiliki alur yang tepat sesuai } \\
\text { dengan kebutuhan sistem? }\end{array}$ & & & & $\sqrt{ }$ \\
\hline 6 & $\begin{array}{l}\text { Apakah desain Data Flow Diagram (DFD) Context Diagram dan } \\
\text { Dekomposisi sudah menggambarkan arus data dari sistem yang } \\
\text { dirancang? }\end{array}$ & & & & $\sqrt{ }$ \\
\hline 7 & $\begin{array}{l}\text { Apakah perancangan Data Flow Diagram (DFD) level } 0 \text { sampai } 1 \\
\text { sudah memodelkan struktur data dan hubungan antar data dengan } \\
\text { tepat? }\end{array}$ & & & $\sqrt{ }$ & \\
\hline 8 & $\begin{array}{l}\text { Apakah hasil desain Data Flow Diagram (DFD) sudah memenuhi } \\
\text { rule check dengan tidak ada kesalahan (no error found)? }\end{array}$ & & & & $\sqrt{ }$ \\
\hline 9 & $\begin{array}{l}\text { Apakah desain form input dan output (user interface) program sudah } \\
\text { sesuai dengan kebutuhan sistem? }\end{array}$ & & & $\sqrt{ }$ & \\
\hline 10 & $\begin{array}{l}\text { Apakah desain tampilan (interface) program merupakan desain yang } \\
\text { user friendly atau mudah dioperasikan? }\end{array}$ & & & & $\sqrt{ }$ \\
\hline
\end{tabular}

Pemrograman Berorientasi Obyek Untuk Meningkatkan Kinerja Laporan Keuangan Pada Toko YK 
4

\begin{tabular}{|c|c|c|c|c|}
\hline & & & & \\
\hline JUMLAH SKOR & 0 & 0 & 9 & 28 \\
\hline JUMLAH SKOR TUNGGAL & \multicolumn{3}{|c|}{37} \\
\hline
\end{tabular}

Tabel 2. Angket Validasi Pengguna/user

\begin{tabular}{|c|c|c|c|c|c|}
\hline No & Indikator & 1 & 2 & 3 & 4 \\
\hline 1 & Apakah tampilan muka sudah sesuai dengan harapan pengguna? & & & & $\sqrt{ }$ \\
\hline 2 & $\begin{array}{l}\text { Apakah tampilan program user friendly sehingga memudahkan user } \\
\text { dalam mengakses? }\end{array}$ & & & & $\sqrt{ }$ \\
\hline 3 & Apakah user merasakan kemudahan ketika melakukan input data? & & & & $\sqrt{ }$ \\
\hline 4 & $\begin{array}{l}\text { Apakah ketika user melakukan kesalahan input data user dapat } \\
\text { dengan mudah mengedit atau menghapus data? }\end{array}$ & & & $\sqrt{ }$ & \\
\hline 5 & Apakah tampilan output sudah sesuai dengan yang diharapkan? & & & $\sqrt{ }$ & \\
\hline 6 & $\begin{array}{l}\text { Apakah user dapat dengan mudah dan cepat mencari data yang } \\
\text { diinginkan? }\end{array}$ & & & & $\sqrt{ }$ \\
\hline 7 & $\begin{array}{l}\text { Apakah preview laporan yang dihasilkan dapat menyajikan laporan } \\
\text { dengan jelas dan akurat? }\end{array}$ & & & & $\sqrt{ }$ \\
\hline 8 & $\begin{array}{l}\text { Dimungkinkan user merasa puas karena informasi yang ada sesuai } \\
\text { kebutuhan pengguna? }\end{array}$ & & & & $\sqrt{ }$ \\
\hline 9 & Pengguna akan terus mengkakses karena dimungkinkan proses cepat? & & & $\sqrt{ }$ & \\
\hline 10 & Apakah user dapat dengan mudah mencetak laporan? & & & $\sqrt{ }$ & \\
\hline & JUMLAH SKOR & & & 12 & 24 \\
\hline & JUMLAH SKOR TUNGGAL & \multicolumn{4}{|c|}{36} \\
\hline
\end{tabular}

Penilaian terbagi atas 4 skor, yaitu:

1. Skor 4: sangat baik/ sesuai

2. Skor 3: cukup baik

3. Skor 2: antara ya dan tidak

4. Skor 1: belum/ kurang

Dalam penelitian ini, respon penguna terhadap penggunaan sistem informasi pembukuan dilihat melalui angket dan nilai. Angket tersebut diberikan kepada penguna sistem umtuk diminta menjawab sejujur-jujurnya atas pertanyaan yang berkaitan dengan pendapat penguna mengenai penggunaan sistem informasi pembukuan pada toko. Adapun persentase skor per item dari masing-masing jawaban angket penguna dapat dilihat pada tabel.

ELKOM Vol. 12, No. 2, Desember 2019: 63 - 71 
5

\section{HASIL DAN PEMBAHASAN}

A. Hasil Pengembanganan

Berikut ini adalah pengembangan dari Sistem Informasi Akuntansi Pembukuan untuk Meningkatkan Kinerja Laporan Keuangan. Program sistem informasi akuntansi pembukuan ini mempunyai tujuan, masukan (input), proses, dan keluaran (output).

1. Tujuan pembuatan program aplikasi sistem informasi akuntansi pembukuan adalah untuk mempermudah pengolahan data transaksi dan penyusunan laporan keuangan.

2. Masukan (input), program aplikasi sistem informasi akuntansi pembukuan ini memiliki masukan (input) berupa transaksi-transaksi pembelian, penjualan, dan penerimaan setra pengeluaran lainya yang berhubungan dengan kegiatan usaha.

3. Proses program aplikasi sistem informasi akuntansi pembukuan ini adalah terciptanya (output) atau informasi (data transaksi dan laporan keuangan).

4. Keluaran (output) dari program aplikasi sistem informasi akuntansi pembukuan ini adalah laporan yang berupa laporan data transaksi, laporan data persediaan barang, laporan laba/rugi, laporan neraca, laporan arus kas, dan laporan neraca saldo.

\section{B. Desain Visual Program}

Berikut ini merupakan tampilan produk sistem informasi akuntansi pembukuan. Berikut ini gambar form-from program sistem informasi akuntansi pembukuan untuk meningkatkan kinerja laporan keuangan.

1. Tampilan Form Login

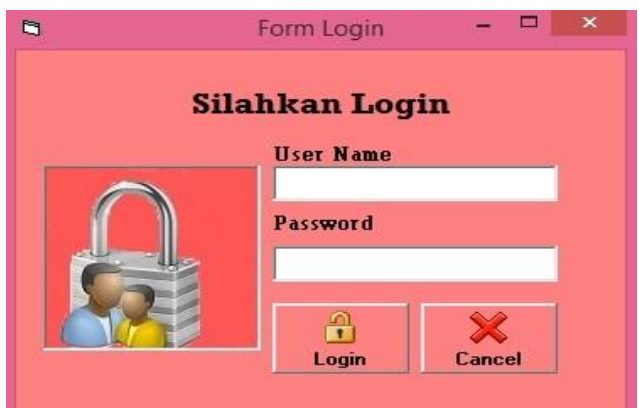

Gambar 1 Form Login

2. Tampilan Form Menu Utama

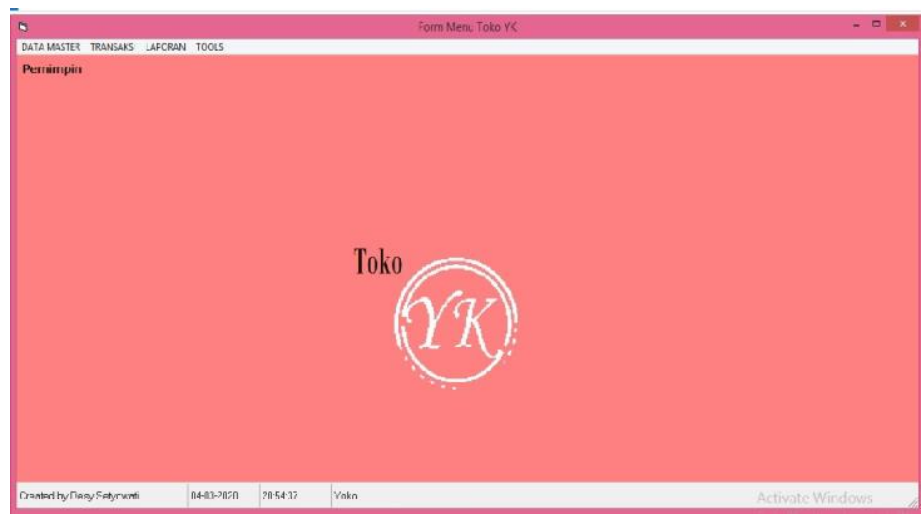

Gambar 2 Form Menu Utama 
3. Tampilan Form Transaksi Jurnal Umum

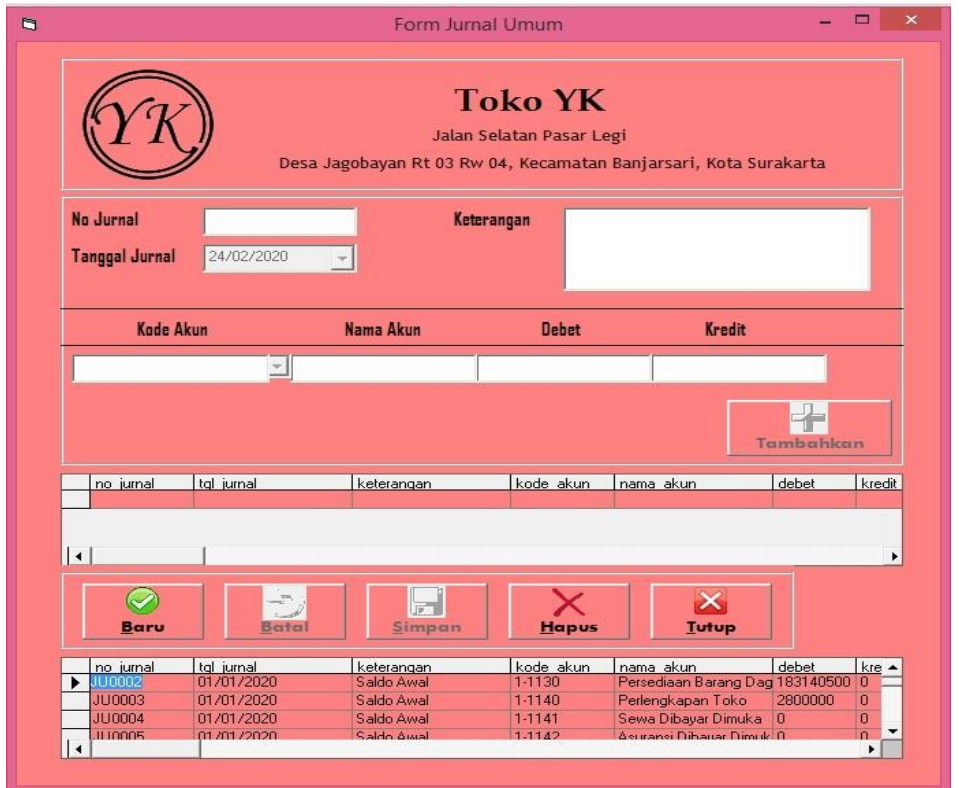

Gambar 3 Form Transaksi Jurnal Umum

4. Tampilan Form Transaksi Buku Besar

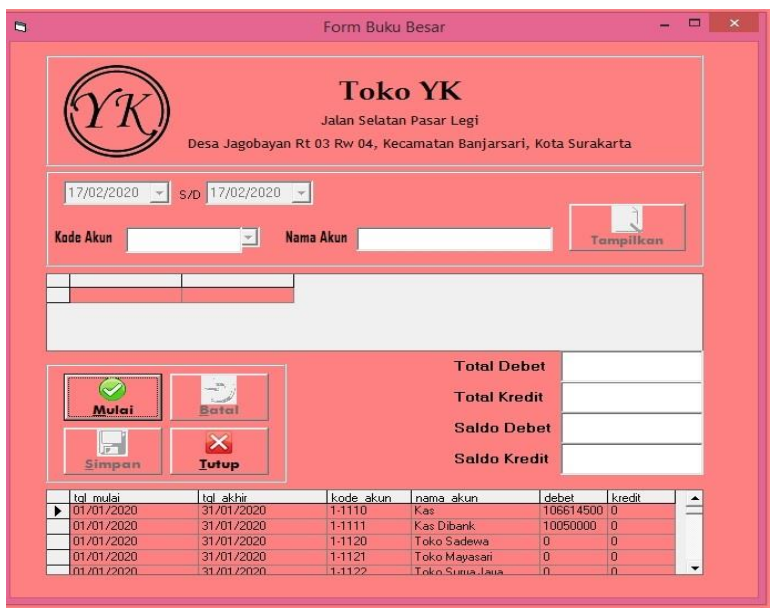

Gambar 4 Form Buku Besar

5. Tampilan Form Laporan Laba Rugi

Toko YK

Laporan Laba Rug Per 31-Januari-2020

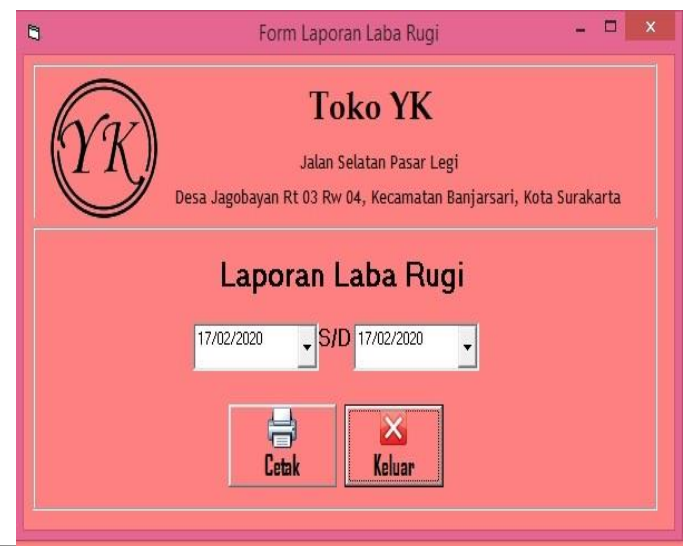

\begin{tabular}{|lrr|}
\hline Penjualan & 0 & 269.900 .000 \\
Retur Penjualan & 0 & 0 \\
Potongan Penjualan & 0 & 0 \\
Harga Pokok Penjualan & 155.930 .000 & 0 \\
Beban Iklan & 350.000 & 0 \\
Beban Listrik dan Telepon & 450.000 & 0 \\
Beban Perlengkapan Toko & 0 & 0 \\
Beban Asuransi & 0 & 0 \\
Beban Gaji & 4.250 .000 & 0 \\
Beban Penyusutan Gedung & 0 & 0 \\
Bebann Penyusutan Kendaraan & 0 & 0 \\
\hline \multicolumn{1}{|c|}{ Laba/(Rugi) Usaha } & \multicolumn{1}{c|}{$108,920,000$} \\
\hline
\end{tabular}

ELKOM Vol. 12, No. 2, Desember 2019 : 63 - 71 
6. Tampilan Form Laporan Neraca Saldo

Gambar 5 Form Laporan Laba Rugi

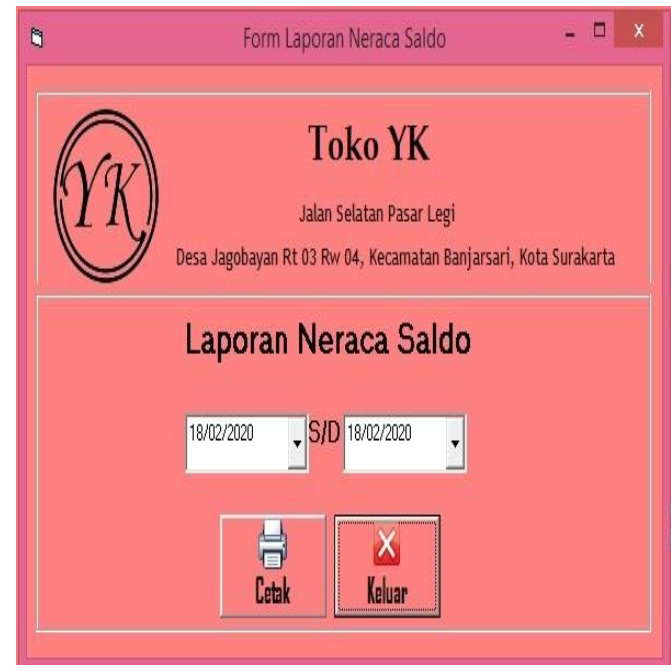

\begin{tabular}{|c|c|c|c|}
\hline \multicolumn{4}{|c|}{$\begin{array}{c}\text { Toko YK } \\
\text { Neraca Saldo } \\
\text { Per 31-Januar-2020 }\end{array}$} \\
\hline kode akun & nama akun & debet & kredit \\
\hline $1-1110$ & Kas & 106.614 .500 & 0 \\
\hline 1-1111 & Kas Dibank & 10.050 .000 & 0 \\
\hline 1-1120 & Toko Sadewa & 0 & 0 \\
\hline 1-1121 & Toko Mayasari & 0 & 0 \\
\hline 1-1122 & Toko Surya Jaya & 0 & 0 \\
\hline 1-1123 & Toko Sari Baru & 0 & 0 \\
\hline 1-1.124 & Toko Ema Jaya & 0 & 0 \\
\hline 1-1125 & Toko Mekar Mandiri & 0 & 0 \\
\hline $1-1130$ & Persediaan Barang Dagan! & 156.955 .500 & 0 \\
\hline 1.1140 & Pertengkapan Toko & 2.800 .000 & 0 \\
\hline 1-1141 & Sewa Dibayar Dimuka & 0 & 0 \\
\hline 1-1142 & Asuransi Dibayar Dimuka & 0 & 0 \\
\hline 1.2110 & Tanah & 50.000 .000 & 0 \\
\hline 1-2111 & Gedung & 60.000 .000 & 0 \\
\hline 1.2112 & Akumulasi Penyusutan G & 0 & 12.000 .000 \\
\hline 1.2113 & Kendaraan & 27.500 .000 & 0 \\
\hline 1-2114 & Akumulasi Penyusutan K & 0 & 5.500 .000 \\
\hline 2-1101 & PD Mulya Jaya & 0 & 0 \\
\hline kode akun & nama akun & debet & kredit \\
\hline $6-1130$ & Beban Perlengkapan Tok & 0 & 0 \\
\hline $6-1140$ & Beban Asuransi & 0 & 0 \\
\hline $6 \cdot 1150$ & Beban Gaji & 4.250 .000 & 0 \\
\hline $6 \cdot 1160$ & Beban Penyusutan Gedun & 0 & 0 \\
\hline $6-1170$ & Beban Penyusutan Kenda & 0 & 0 \\
\hline Total & & 575.900 .000 & 575.900 .000 \\
\hline
\end{tabular}

Gambar 6 Form Laporan Neraca Saldo.

\section{Pembahasan Produk Akhir}

Tahap pengujian perangkat lunak atau sistem informasi akuntansi pembukuan untuk meningkatkan kinerja laporan keuangan ini sangat diperlukan. Hal ini untuk mengurangi atau menghilangkan terjadinya kesalahan pada saat aplikasi tersebut digunakan. Pengujian perangkat lunak ini berfokus pada pengujian persyaratan fungsional perangkat lunak, untuk mendapatkan serangkaian kondisi input yang sesuai dengan persyaratan fungsional atau program.

Bagian ini akan digunakan pengujian pada proses registrasi user yaitu melalui hak akses login, untuk melakukan verifikasi dan validasi sebelum masuk ke Menu Utama.

\section{C.1. Hasil Uji Pakar Internal}

Pada Tabel 3 berikut adalah hasil validasi pakar internal

Tabel 3 Penilaian Validasi Pakar Internal

\begin{tabular}{|c|c|}
\hline Nomor Pertanyaan & Skor yang dihasilkan \\
\hline 1 & 4 (poin) \\
\hline 2 & 3 (poin) \\
\hline 3 & 4 (poin) \\
\hline 4 & 4 (poin) \\
\hline 5 & 4 (poin) \\
\hline 6 & 4 (poin) \\
\hline 7 & 3 (poin) \\
\hline 8 & 4 (poin) \\
\hline 9 & 3 (poin) \\
\hline 10 & 4 (poin) \\
\hline Total Skor & $\mathbf{3 7}$ (poin) \\
\hline
\end{tabular}

Pemrograman Berorientasi Obyek Untuk Meningkatkan Kinerja Laporan Keuangan Pada Toko YK 
Dari tabel hasil pengujian pakar melalui angket yang berjumlah 10 pertanyaan diperoleh skor sebesar 37 poin. Hal ini membuktikan bahwa desain sistem informasi yang dirancang dinyatakan sangat baik atau valid.

\section{C.2. Hasil Uji lapangan (Pengguna/User)}

Pada Tabel 4 berikut adalah hasil validasi pakar internal

Tabel 4 Penilaian Validasi Pakar Internal

\begin{tabular}{|c|c|c|c|}
\hline \multirow{2}{*}{$\begin{array}{c}\text { Nomor } \\
\text { Pertanyaan }\end{array}$} & \multicolumn{3}{|c|}{ Pengguna atau User } \\
\hline & Admin & $\begin{array}{c}\text { Bagian } \\
\text { Keuangan }\end{array}$ & Pimpinan \\
\hline 1 & 3 (poin) & 4 (poin) & 4 (poin) \\
\hline 2 & 3 (poin) & 4 (poin) & 4 (poin) \\
\hline 3 & 4 (poin) & 4 (poin) & 4 (poin) \\
\hline 4 & 3 (poin) & 3 (poin) & 3 (poin) \\
\hline 5 & 4 (poin) & 3 (poin) & 4 (poin) \\
\hline 6 & 4 (poin) & 4 (poin) & 4 (poin) \\
\hline 7 & 3 (poin) & 4 (poin) & 4 (poin) \\
\hline 8 & 3 (poin) & 4 (poin) & 4 (poin) \\
\hline 9 & 4 (poin) & 3 (poin) & 3 (poin) \\
\hline 10 & 3 (poin) & 3 (poin) & 4 (poin) \\
\hline Total Skor & 34 (poin) & 36 (poin) & 38 (poin) \\
\hline
\end{tabular}

Skor rata-rata yang diperoleh berdasarkan jumlah skor dari calon user di atas yaitu:

Skor rata-rata $=\frac{34+36+38}{3}=36$ (Sangat Baik)

Dari tabel hasil pengujian user melalui angket yang berjumlah 10 pertanyaan diatas diperoleh skor rata-rata 36 poin. Berdasarkan nilai yang diberikan oleh pemakai Toko YK. Produk yang dihasilkan berdasarkan skor di atas adalah Sangat Baik dan menandakan produk tersebut diterima dengan baik di Toko YK.

\section{KESIMPULAN}

Setelah melakukan penelitan, ada beberapa kesimpulan yang diperoleh dari hasil pengujian, yaitu sebagai berikut;

1. Jurnal menggunakan metode perpetual dapat diterapkan pada setiap transaksi.

2. Pengelolaan untuk persediaan barang dagangan sudah tersedia dan terhubung langsung dengan transaksi.

3. Sistem Informasi Akuntansi Keuangan dapat menghasilkan output berupa Laporan Keuangan.

ELKOM Vol. 12, No. 2, Desember 2019: $63-71$ 


\section{DAFTAR PUSTAKA}

[1] R. D. Utami, "Sistem Informasi Laporan Keuangan Perusahaan Dagang Berbasis Multiuser," akuntansi, pp. 1-17, 2014.

[2] S. M. K. Sugiono Arif., Yanuar Nanok Soenarno., Akuntansi dan Pelaporan Keuangan. j: Grasindo, 2009.

[3] C. S. Agustin Setyaningrum., Annisa Febrian., Ayu Nadia Hanum., Aisyah Dian Pratiwi., Vivi Zuryati., Akuntansi Suatu Pengantar Berbasis PSAK. Jakarta: Salemba Empat, 2016.

[4] Sugiono, Metode Penelitian Kuantitaif, Kualitatif dan R\&D. Bandung: Alfabet, 2015. 